I/S: A JOURNAL OF LAW AND POLICY FOR THE INFORMATION SOCIETY

\title{
Democratic Information Communities
}

\author{
PETER M. SHANE*
}

Abstract: In order that American communities may thrive in a $21^{\text {st }}$ century democratic context, both individuals and organizations across the private, public, and nonprofit sectors must intentionally dedicate themselves to promoting an inclusive flow of information designed to support collective problem-solving, the coordination of community activity, public accountability, and connectedness within the community. Our national commitment to democracy to ideals of political liberty and equality - means not only that local communities need information adequate for these purposes, but that our practices of information creation, organization, analysis, and transmission need also to be democratic in character. This creates a special community need for good journalism, for a for-profit media environment attentive to issues of access, diversity, relevance, and media power, and for nonprofit institutions that develop and organize information in the public interest that assist communities by actively facilitating democratic conversation for community agenda-setting, problemsolving and conflict resolution. Communities that pursue

\footnotetext{
* Jacob E. Davis and Jacob E. Davis II Chair in Law, The Ohio State University. As described above, I wrote most of what appears here during my service as executive director of the Knight Commission on the Information Needs for Communities in a Democracy, to assist in the Commission's deliberations. This article, however, does not represent the views of the Knight Commission, the John S. and James L. Knight Foundation, the Aspen Institute, or any of their programs. I am grateful for the exceptional research assistance of Musetta Durkee, who served as research associate to the Aspen Institute Communications and Society Program during this project.
}

Copyright (C) 2010 by Peter M. Shane and The Aspen Institute. This work is licensed under the Creative Commons Attribution-Nocommercial 3.0 United States License. A copy of this license appears at http://creativecommons.org/licenses/by-nc/3.0/. 
these aims should be considered "democratic information communities."

\section{PREFACE}

The Knight Commission on the Information Needs of Communities in a Democracy was first proposed at an August 2007 forum on communications and society, sponsored by the Aspen Institute. Aspen is a Washington, D.C.-based nonprofit organization dedicated to fostering high-level discussions of pressing public policy issues. The John S. and James L. Knight Foundation agreed to fund the Commission, which Aspen would then organize and administer. The Commission comprised 17 distinguished figures from the worlds of media, technology, public policy, and community organization and issued its final report on October 2, 2009 (Knight Commission 2009). From January 2008 through October 2009, I had the good fortune to serve the Commission as its executive director. Part of that engagement involved serving as lead author of the Commission's final report, although my task was not to present my own views, but to capture the common thinking of the Commission's diverse and thoughtful members.

In the course of helping the Commission, it was also necessary to organize a great deal of research and to provide some of my own thinking, mainly as a foil for member reactions. One vehicle I used was a paper, presented in August, 2008, which was intended to provoke Commissioner responses to the key question underlying the Commission's work: "What are the information needs of American communities in our $\mathbf{2 1 ^ { \text { st } }}$ century democracy?" What follows is the core of that discussion. It argues that, in order to fulfill their potential, American communities in the $21^{\text {st }}$ century democracy need to become fully "democratic information communities."

\section{THE IDEA OF A DEMOCRATIC INFORMATION COMMUNITY}

The idea of a democratic information community implies more than the descriptive term, "information society"-that is, a society in which information has become a primary source of economic value and a product around which social and economic life is organized (Bell 1973). It implies a normative self-concept-an aspiration that healthy democratic communities should have for themselves. In a democratic information community, both individuals and organizations engaged throughout the private, public, and nonprofit sectors intentionally dedicate themselves to promoting an inclusive 
flow of information. They intentionally do so in a manner designed to support collective problem-solving, the coordination of community activity, public accountability, and connectedness within the community. This framework thus understands "the information needs of communities" to entail not just a set of concrete needs for particular forms of information creation, access, organization, and dissemination. It needs a set of democratically oriented information institutions and practices, plus a set of social and political conditions in which they are most likely to thrive. These practices and background conditions cannot simply be willed into permanent existence. Achieving and maintaining them in any community requires a conscious community reorientation towards the value of information and the importance of democracy.

\section{WHY CARE ABOUT LOCAL COMMUNITIES?}

For democracy to thrive, it is important to focus on real-space communities and their members. Despite the omnipresence of electronic networks, people still live in geographically defined clusters typically characterized by relative physical proximity to one another. They share governance over, and a dependency upon, some identifiable domain of common resources. Focusing on the information environment of localized human communities is critical for three reasons.

First, the quality of the geographical locale in which individual citizens live is centrally connected to their life opportunities and their health and welfare: "Place affects our access to jobs and public services (especially education), our access to shopping and culture, our level of personal security, the availability of our medical services, and even the air we breathe" (Dreier, Mollenkopf, and Swanstrom 2004, 4). Research suggests that people's neighborhood environment is a significant factor in determining their physical exercise levels (Wen, Browning and Cagney 2007). Urban planning scholar Richard Florida has observed that, while globalization has diffused a wide range of economic resources and functions, "higher-level economic activities such as innovation, design, finance and media . . . cluster in a relatively small number of locations" (Florida 2008, 19). $\mathrm{He}$ concludes: "Despite all the hype over globalization and the 'flat world,' place is actually more important to the global economy than ever before" (Ibid., 12).

Second, the representative institutions of our democratic governance are organized geographically. Federalism, along with the separation of powers, is one of the key organizing principles of 
American government. The U.S. Constitution reserves certain areas of social welfare regulation entirely to the state level, and states routinely delegate significant authority to counties, cities, and towns. Even for those programs that the federal government administers, a common strategy is to provide funding and nominal supervision at the national level for programs of implementation that are organized and fulfilled by state and local authorities. Among our political events, presidential elections may get the lion's share of media attention. But the public officials most responsible for the impact of government on the quality of Americans' day-to-day lives are typically elected or appointed by the states, counties, and cities or towns in which we live.

Third, the advantages the internet has brought to Americans in connecting with issues and organizations on a national and even global scale have outpaced developments in promoting local information flow. The most highly trafficked news and information sites on the Web remain those affiliated with national media brands (Nielsen, Neilsenwire, posted April 21, 2009). Meanwhile, the consolidation of media ownership among national media enterprises has created greater economies of scale for the development and dissemination through both broadcast and web outlets of national and global, but not local, news ${ }^{1}$ (Grossman 1995, 115-118).

Fortunately for local communities, new online applications supporting both localized search and the collaborative creation and distribution of information have initiated an exciting period of creative initiatives targeted at local information. Moreover, these private and nonprofit initiatives co-exist with significant efforts by many state and local governments to make pivotal information available online to the general public. Yet, robust local initiatives of this sort are far from universal. Many Americans would undoubtedly find it easier to track developments in the U.S. Environmental Protection Agency (EPA) than in their own city council, or to learn the facts of a salmonella outbreak across the country, as compared to finding out the health inspection results for local restaurants.

\footnotetext{
Reviewing news for calendar year 2007, 25 percent of the top stories on online sites dealt with non-U.S.-related foreign stories, as compared to 13 percent of the top stories in newspapers, 8 percent on television networks, 7 percent on radio news, and 4 percent on cable news (Project for Excellence in Journalism 2008, page 2).
} 


\section{HOW Do COMMUNITIES USE INFORMATION?}

Communities involve more than the geographical co-location of individual human beings. A community is a complex social system in which the actions and interactions of individual members produce collective outcomes that often cannot be traced, in any simple linear fashion, to the isolated decision making of individuals. What binds this system together is the flow of information; when systems of communication change, the collective phenomena that emerge from human interaction change, too (Sawyer 2005).

The individuals who form communities use information in at least four distinct, though overlapping ways: to coordinate collective activity, to achieve public accountability, to solve problems, and to create connectedness.

The idea of coordination is straightforward. Many group activities can succeed only if everyone knows where to be at what time and playing what role. Sometimes, the when, where, and how of a community activity-such as, an election-are established by legal requirements, and the details can be shared well in advance. But not always. The local emergencies caused by catastrophic weather events or outbreaks of serious illness illustrate the kinds of collective activities that can be anticipated in general terms, but not wholly preplanned. The better coordinated a community's response in the face of an emergency, the less the likely adverse impact on everyone's health and welfare. Similarly, the effectiveness of social service activities subject to advance planning is likely to depend on provider information about where services are needed and on recipient knowledge of how to obtain those services. Even community celebrations, such as July $4^{\text {th }}$ fireworks displays, marathons, and festivals of all kinds, may go better or worse depending on the effective distribution of information about traffic patterns and participation requirements.

The idea of accountability is also basic. In a representative democracy, citizens are entitled to hold public officials accountable for their performance in office. They can perform that function only if information is available as to who is responsible for which decisions or implementation functions, and the outcome of their work. If no one knows how city councilors vote, for example, no one knows whose positions merit their support or opposition. If no information is available on the academic performance of public school students or on local crime rates, no one can intelligently assess whether members of the local Board of Education or the police commissioner, respectively, 
are succeeding at their jobs. To the extent such authorities are appointed, rather than elected, it is not possible to determine whether the elected officials responsible for the appointments have selected good candidates and supervised them effectively.

Accountability also extends to the private sphere. Within constitutional limits, state and local authorities are entitled to regulate private economic activity that adversely affects public health, safety, or welfare. Whether any such regulation is either necessary or effective can hardly be assessed without information about the behaviors of private firms that may affect the public interest. The Toxics Release Inventory, a publicly available EPA database that contains information on toxic chemical releases and waste management activities by both government facilities and private industry, exemplifies this sort of data (Environmental Protection Agency).

The relationship of information to problem-solving is complex. John Adams famously said: "Facts are stubborn things; and whatever may be our wishes, our inclinations, or the dictates of our passion, they cannot alter the state of facts and evidence." Access to facts is presumably necessary for the effective solution of any community problem from outdated infrastructure to downtown business revitalization. But problem-solving rarely, if ever, springs straightforwardly from the ascertainment of undisputed facts to the implementation of a uniquely plausible response. As a general matter, community problem-solving comprises five different elements:

- the identification of a problem or determination of a community goal;

- developing options for addressing the problem or goal;

- estimating the consequences of the various options;

- weighing those consequences in light of both economic costs and other community values, and

- determining which option to pursue (Price and Neijens 1997). 
These are likely to involve different groups of people at different times, and are unlikely to proceed neatly in analytic order.

Democratic problem-solving thus entails multi-directional discussion, sometimes plainly deliberative in character, but frequently spontaneous, free-flowing, and proceeding without formal structure. Outcomes follow only partly from basic facts, but significantly also from values as they emerge through a sharing of attitudes, perspectives and evaluations-a process of sharing that itself involves a highly complex information flow through conversation, storytelling, private chat and public testimony-virtually all the forms of talking and listening in which a community can engage.

Beyond each of these three fairly instrumental uses of information, community members depend on information for another, perhaps harder to measure outcome: connectedness. For people to prosper together in relatively peaceful, prosperous communities, they have to understand themselves to be part of a group sharing some degree of common interest and destiny. Such self-understanding arises from acts of communication that give us ideas, symbols, facts, and perspectives that, through conscious and unconscious processes, we weave into narratives that help us understand who we are and our relationship to other people (Fireman, McVay, and Flanigan 2003). Media and public institutions as well as individual community members engage in this process of self-understanding, together creating a sort of collective, shared system of meaning that is always in flux as new voices and new experiences enter the information flow. Such a system of meaning enables people from different groups to interact effectively across family, friendship, and neighborhood networks.

\section{THE DEMOCRATIC CONNECTION}

Information flow is critical to the fulfillment of four community needs: coordination, accountability, problem-solving, and connectedness. What these needs actually mean in practice, however, and how information properly relates to their fulfillment are both critically shaped in the American context by our national commitment to democracy.

The idea of a commitment to democracy is not simple. People sometimes use "democracy" and "democratic" in a purely descriptive sense, to identity a particular way of organizing government and a set of procedures for making public decisions. In this vein, political scientists even subdivide democracies into a variety of types-direct democracy, representative democracy, associative democracy, and the 
like. For most Americans, however, the word "democracy" is presumably intended to capture something deeper. Democracy implies a special moral relationship of the government to the public it serves. This is a relationship that makes government legitimate, that entitles a relatively few citizens to make laws and issue commands that properly bind their fellow citizens. Democracy, in this sense, is more than a description; it is an ideal.

In fact, the procedures and forms of organization that we describe as democratic are perhaps best understood as means to achieving two ideals on which democratic legitimacy rests. One is the promise of political freedom-that our system of government will provide for all citizens the maximum opportunity to experience themselves as meaningful actors in public life to the extent they choose to participate. Everyone may share in meaningful acts of collective selfdetermination (Post 1995). Voting in fair elections is one of our most critical expressions of that liberty, but, without free public discussion, the concept of a democratic election is virtually meaningless. Individually and in groups, people stage electoral campaigns, petition government to respond to their concerns, organize in support of issues and causes in which they believe, and seek through public words and actions to help shape community opinion. It is through a complex system of both formal and informal actions that Americans expect to participate freely and fully in shaping the laws that bind them.

The second ideal on which democratic legitimacy rests is the promise of political equality. Democracy is intended to assure, to the maximum extent possible, that government decision-making takes into serious account the interests of everyone affected by those decisions (Buchanan 2002). Within a democratic self-governing community, no member's interests may be disregarded because of race, religion, sex, age, place of birth, political beliefs, or any other aspect of status unrelated to a person's moral entitlement to the concern of others (Thompson 2008). This is not to say that all decisions are made by consensus or that anyone is guaranteed equal happiness with the outcome of every community decision. Western democracy, however, is founded on the premise of the moral equality of all human beings. The moral equality of all human beings implies a community obligation to take seriously the interests and concerns of all.

Our national commitment to democracy as an ideal, not just a description - as embodying the promises of both political freedom and political equality - has profound implications for a community's information environment. It is not merely the quantity of available information that primarily determines whether a community is justified in regarding itself as truly democratic. A community's 
democratic character depends on how information is actually used to achieve coordination, public accountability, problem-solving, and connectedness. Achieving these ends implicates not merely the production of information, but also its organization, dissemination, and discussion. The imperative to conduct each function in service of democracy implies that all of these facets of information processing must themselves take on a democratic character.

Coordination provides perhaps the simplest case. To mobilize people and resources democratically to address community needs, information must be both designed and disseminated to reach with equal effectiveness everyone who could benefit from the resources in question or, without whose participation, the effectiveness of the community mobilization would be reduced. As an example of positive media behavior, Michael Coleman, mayor of the city of Columbus, Ohio, cites the efforts of both print and broadcast media to inform Columbus residents that a long-dormant youth curfew law would, in fact, be enforced during the summer of 2008. ${ }^{2}$ He believes that, given the media's comprehensive approach and his office's proactive efforts, probably ninety percent of Columbus families with children 17 years of age or younger became aware of the curfew, and its implementation met with very few problems. Had the Mayor's office not taken a proactive role, if media had rejected their responsibility to disseminate information critical to community coordination, or if the media had selectively delivered the curfew message to only a few of the neighborhoods affected-all quite unlikely scenarios, to be sure-it would have marked not just a failure of policing, but a failure of democracy.

The imperatives of accountability, problem-solving, and connectedness are more complex. The information relevant to these functions is vast in volume, frequently technical or highly detailed, sometimes difficult to acquire, and almost always susceptible to conflicting evaluations and interpretations. Any effectively selfgoverning community will aspire to an information environment that somehow translates the flow of such information into public accountability, democratic problem-solving, and an inclusive sense of community belonging and solidarity. This "translation," however, is not a simple process.

No human being has the time, skill, and energy to ferret out, analyze, and preserve all of the information on which an individual relies, either in one's private affairs or for participation in public life.

2 Michael Coleman (Mayor, Columbus, Ohio), interview by author, Columbus, Ohio, July $2,2008$. 
The fair, accurate, contextual search for truth is a process in which people can typically engage only with a regard to a narrow range of their personal concerns. Individuals and organizations thus all rely on a host of formal and informal "information intermediaries," people and institutions that create information, identify its relevance, sort out the important details, contextualize its significance to us, and offer their evaluations. Family, friends, and co-workers all play this function, as do government, the institutions of civil society, and a host of formal "media" institutions, including print, broadcast, satellite, cable, and online venues.

Such intermediaries may differ as to their energy, interests, motives, discernment, interpretive skill, and animating values-all of which are likely to shape the information as it is passed to us. This is not just a matter of conscious "spin." Just as human beings have to apply our reason to the information that eventually reaches us, our intermediaries all have to reason their own way to determinations as to what information is both valuable and trustworthy. Linguist George Lakoff points out: "The cognitive and brain sciences have shown that reason ... uses frames, metaphors and melodramatic narratives [and] varies depending on worldview ..." (Lakoff 2008). Modern cognitive psychology starts from the premises that the human brain is limited in its capacity to process information, and that this limitation causes human beings to make decisions through certain forms of mental shortcuts, which can produce a predictable set of judgment errors (Rachlinski and Farina 2002). Information intermediaries will sometimes try to select or present information with a purposeful slant, but, even when they do not, they, like their audiences, are subject to the cognitive limitations that condition how people understand and transmit information.

A democracy protects itself from the distorting effects of any one intermediary by embracing a sort of "checks and balances" within its communications environment. A genuinely democratic information environment requires a pluralistic system of intermediaries that makes available and is genuinely responsive to multiple frames, narratives, and worldviews, not all of which will be consistent. Such pluralism sustains the hope that a locality's communication pathways will cumulatively bring information to the public in a way that is ultimately attentive to the interests, needs, opinions, or perspectives of every subset of the community-thus, protecting political equality. Moreover, unless communication pathways are open to the full span of community voices interested in shaping the locality's shared narrative and helping to set the direction of public affairs, a significant measure of political freedom will not be available to all. 
An important implication of this analysis is that, when it comes to public accountability, one of a democratic community's primary information needs-"transparency" in the operation of a government-is a necessary, but not a sufficient condition. Our national government, the District of Columbia, and all fifty states have open government laws that, to various degrees, guarantee public access to an enormous volume of public records and proceedings. 3 By itself, however, that access can provide only limited assurance of accountability unless recourse to such information is embedded in the information practices of knowledgeable information intermediaries and the decision making practices of voters and community institutions (Fung, Graham, and Weil 2007). A balanced understanding of such information requires that its significance be widely discussed and debated among people whose approaches to information involve different interests, perspectives, and knowledge.

\section{JOURNALISM}

Among the information intermediaries present within any community, one subclass holds a special relationship to democratic life: journalists. Although the practice of journalism defies air-tight definition, its core was well captured by the 1947 Hutchins Commission Report on a Free and Responsible Press-providing "a truthful, comprehensive, and intelligent account of the day's events in a context which gives them meaning" (Hutchins 1947, 20). This activity comes in many flavors, and may be practiced from a variety of motives, but the core journalistic practice on which democratic communities depend is journalism characterized by independence of judgment. Good journalism is designed not to serve any special economic interest or the interests of those in power, but selects information for presentation and judges its quality only according to the interests of the public at large (Overholser 2006; Scheuer 2008).

Journalists necessarily operate in the context of a particular audience, whose projected needs and interests form the basis for the editorial selection of stories to cover and of various informed opinions to share in order to help audience members clarify their goals and values. It is not that local communities need only local informationthe facts and circumstances that give meaning to local events may well extend to other communities or a larger geographic scope. But local

3 The federal Freedom of Information Act appears at 5 U.S.C. $§ 552$. Links to the D.C. and state open records laws appear on the site of the National Freedom of Information Center, http://www.nfoic.org/foi-center/state-foi-laws.html. 
communities need journalism that is truly local journalism - that is, "a truthful, comprehensive, and intelligent account of the day's events" selected with a local audience in mind and presented "in a context which gives them meaning" to that local audience by virtue of the geographic space that the community shares.

There are four critical reasons why journalism as a distinct practice is an essential component to the information infrastructure of a democratic community. First, there is a daily unfolding of so much information on which successful community life depends that no one who has a full-time job other than journalism, no matter how motivated, can possibly hope to sift through all of it. Among the many information intermediaries on which community members rely, there must be some with sufficient training, resources, determination, and independence of judgment to assist us in identifying what is most likely to be crucial to the life of the community.

Second, not everything that presents itself to us as information is true, and much of it is complex. Communities depend upon some class of information intermediaries sufficiently knowledgeable to separate information that is reliable from information that is not, and to render even technical information on complicated subjects comprehensible to non-experts.

Third, a lot of the information that is important to the community arises in obscure settings or is connected to the life of the community in ways that may not be obvious to non-experts. Information does not step forward to announce its relevance; it must be pursued. Much valuable information arises from closed-door meetings or in specialized forums. The background that makes such information meaningful may come from other times ("What happened in history?"), or other places (“What's happening out of state?"). Locating and translating that background to make it relevant to understanding the current moment is itself an intellectually demanding and time-consuming enterprise that most members of a community will not and perhaps cannot pursue except with regard to a small range of matters in which they have a deep personal interest.

Finally, with regard to both problem-solving and achieving accountability, people who have the information that the public needs in order to reach a responsible judgment are often motivated to withhold that information from public scrutiny. The motivations may be fairly neutral-a harried and overworked government official may simply not want to have to relate decisions that are entirely justified, but which she finds time-consuming to explain. Too often, the motivations will be self-interested or even corrupt. But, whatever the motivations for shielding information, in such cases, only an information intermediary with resources and training to investigate 
the recalcitrant can bring to light what the community needs to know. This is why the literature on journalism and democracy so commonly stresses the journalists' watchdog role. It is not enough that reporters wait passively for the malfeasance of public officials to expose itself; journalists must be actively engaged in the pursuit of information that will prompt exposure.

Communities' need for journalism does not itself guarantee that the conditions for excellent journalism are everywhere present. Journalists, like most adult citizens, need to make a living. They need access to knowledge and training for the development of their skills. They need a legal environment protective of their function-whether in securing the right to free expression, guaranteeing access to public records, or limiting their vulnerability to personal liability when, as is inevitable, their work turns up facts that are critical, unpleasant, or embarrassing. Indeed, because their efforts often work to the discomfort of powerful people and institutions, journalists need their fellow citizens' support and understanding of their function. A public antagonistic to critical news is too likely to get little news at all.

In sum, democratic communities need to help to prioritize and render both accessible and meaningful the news of daily events that citizens cannot possibly monitor on their own. This includes, most emphatically, "watchdogging" those in power. Without good journalism, the democratic coordination, problem-solving, accountability, and connectedness on which communities depend seem all but unimaginable. Communities need an economic, legal, and social environment that values good journalism.

\section{MEDIA}

Within any community, a limited set of information intermediaries-television (in all of its forms), radio, and "mainstream" print publications-invariably hold the largest audience. These are "the media," sometimes now called "old media," "traditional media," or "legacy media." What has typically characterized these institutions, at least through most of the twentieth century, is the asymmetrical relationship of the speaker-that is, the individual broadcaster or publisher-and its mass audience (Bimber 2003). A few broadcasters or publishers, enlisting the special powers of presentation available to well-resourced media firms, are able to convey their messages to a large number of people, while the audience has few, if any opportunities to respond to or contest those messages with real effect. What contrasts the traditional forms of media from "new media" is precisely the latter's capacity to support interactive 
communication. Although the adoption of new media practices by old media firms makes the old-versus-new categorization problematic, the fact remains that the one medium in virtually every community holding the greatest public attention remains television in the traditional "mass media" mold. Whether the internet yet fully equips a local community audience to respond effectively to the messages of broadcast television is an open question.

From the standpoint of democracy, members of the media have created both unique opportunities and unique challenges. As vehicles for getting accessible information to the public in a powerful way that successfully engages human attention, the media are unsurpassed. When the media devote themselves to good journalism, the consequences are positive. Media successes in exposing corruption, bringing social problems to national attention, and equipping the public generally with information to improve their lives, both individually and collectively, are innumerable.

At the same time, the media pose special challenges for democracy. When we combine the ideals of democratic life, political freedom and political equality, with the ways in which communities use information, for problem-solving, coordination, accountability, and connectedness, four immediate concerns are posed when media predominate over other information intermediaries: access, diversity, relevance, and media power.

If certain intermediaries have greater power than others to create, organize, and disseminate information, whether on a local or national basis, members of the public who lack access to those intermediaries are cut off from the dominant cultural and political conversation. Access, in this sense, has multiple dimensions. There may be neighborhoods or even regions that, for reasons of geography and economics, are cut off from particular media platforms altogether. In other cases, media technologies may be locally available but beyond the economic means of particular households. Even when a household can afford the necessary technology, members may lack effective access-especially to new media technology-because they lack the training and skills to deploy that technology most effectively for their own purposes. Research suggests that the most enduring forms of "digital divide" are likely to be social, involving skills and knowledge, rather than technological (Hargittai 2002).

Diversity is likewise a multi-dimensional concern. The ideal of political freedom entails the hope of an effective voice in the democratic conversation for any willing participant; the ideal of political equality promises responsiveness to the concerns and perspectives of all. Yet, the small number of media "speakers" in relation to the audience, and the expense typically associated with 
becoming an effective speaker in the media universe, mean that very few people in any community speak directly through the media, and they are unlikely to be representative of the community as a whole in terms of social and economic background. The regulatory regime for cable television has sought to ameliorate these limitations through the mandatory availability of public access channels, but these rarely, if ever, command the attention of the larger and better-resourced media outlets in any community.

The concern for diversity has ramifications for the issue of relevance. Subgroups within any community, and the community as a whole, will suffer if available media do not address concerns relevant to the local community. Even though not all locally relevant information is itself local, much surely is. Yet, not all media outlets will find it profitable to devote time and resources to the capturing, organization, and transmission of local information. If people's "information time" is consumed disproportionately-perhaps even entirely-by conversation that is not truly relevant to local community welfare, the quality of problem-solving, accountability, coordination, and connectedness must inevitably suffer.

Each of these three issues touches on the overarching theme of media power, the capacity of a few speakers to shape public understanding through the framing and prioritization of issues. But the issue of media power goes further than the questions of who controls or speaks through media outlets. The predominance of media in our local and national information infrastructures means that conventions for the presentation of information in the media become part of how people "read" the nature of what is being presented to them. Programs featuring an "anchorperson" behind a desk, shown around the dinner and bedtime hours, signal "news." Serious-sounding interviews with credentialed individuals signal "expertise." Stories presented at the top of a newscast signal "importance." Increasingly, however, the media have blurred these signals. Paid advertisements with no intent other than sales are presented in a genre calculated to imitate news. People offered as experts are sometimes paid advocates for particular points of view, but not clearly identified as such. A news story may be chosen more for sensation than importance. In all such cases, media have an inherent capacity, whatever the speaker's conscious agenda, to distort a community's self-understanding and to shape public debate in ways ill-suited to achieve the public interest.

Members of the media thus play a role in democratic communities that is both essential and problematic at the same time. No information intermediary has comparable capacity to reach so many people effectively. The power of media to bridge small information 
networks within communities, and to help nurture a sense of community identity that either crosses or reinforces lines of family or neighborhood, is enormous. Media facilitate community coordination when accurate information about community needs, opportunities, and processes is widely diffused. Media journalists can be a community's most effective watchdogs over both public authorities and powerful private actors. Their capacity to share information critical to community problem-solving is unparalleled.

But all this potential coexists with risk. The risk is that the relatively narrow range of media ownership and access, and unreflective uses of the media that result in the distorted presentation of information, can subvert democratic processes. The key for successful communities is thus to create and maintain a media environment with sufficient attention to media access, diversity, relevance, and power, so that the media serve and not undermine the aims of genuinely democratic discourse. In that way, media can become the instruments of democratic coordination, problem-solving, accountability, and connectedness that successful communities need.

\section{MARKET FORCES, NONPROFIT INSTITUTIONS, AND DEMOCRATIC INFORMATION FLOW}

The creation, organization, analysis, dissemination, and storage of information take resources. As in most things, Americans have long relied on private markets to generate the resources adequate to meet their information needs, and the record of private sector institutionsmost notably, privately owned media-includes much that is admirable. Institutions based in the for-profit private sector have advantages in terms of flexibility and innovation when it comes to developing and deploying new technologies and business models for the benefit of large numbers of information consumers, and it is hard to imagine Americans would have anything like the range of tools and information sources available to us today without reliance on free enterprise.

Nonetheless, information institutions governed primarily by market forces will predictably under-produce at least some of the information critical to community success. First, for broadcast radio and television, individual citizens only rarely get to vote directly with their dollars for the media content provided. Even for subscription media, such as newspapers, magazines, and basic cable, consumer dollars may pay for only a fraction of the cost of producing information. In such cases, commercial discipline is exercised chiefly by the advertising market, and advertisers' preferences for content 
that will deliver audiences to their product and services may or may not correspond with consumers' own preferences or needs for the information or content that they would most wish to elicit.

Second, the commercial orientation of for-profit media is likely to discipline the range of issues and perspectives covered, as well as the way information is presented. To take an obvious example, the issue of media ownership-and whether there should be legal limitations on the concentration of ownership-has been a subject of intense debate before the Federal Communications Commission, the courts, and among media experts. Whatever one's position on the issue, its significance in terms of the competing interests involved can hardly be doubted. Yet, a July 20, 2008 electronic search of the online Westlaw USNP database for "United States newspapers" for the terms "media ownership" or "media concentration" in news items published during the past three years elicits just over 1200 items in a database of 400 commercial newspapers. This figure includes news stories and letters to the editor, with an average of one published item mentioning these phrases per newspaper per year. This compares during the same period with more than 6200 items on "Botox" and 10,000 for "iPhone." To the extent this accurately reflects the degree of media coverage of "media concentration" as an issue, it is hard not to read these figures as a sign that media's self-regarding perspective may be affecting the scope of coverage.

There are two other, arguably more profound reasons why exclusive reliance on for-profit information intermediaries is unlikely to achieve the optimal community information flow. First, much local news and information fits the economic definition of a "public good." It is a "good, that is, that is "nonrivalrous" and "nonexcludable." It is "nonrivalrous" because no one person's consumption of local news reduces its availability to anyone else. It is "nonexcludable" because, once someone pays for the production of local news, members of the community who did not pay for its production still benefit from it. (Imagine, for example, a news story in my community that forces a corrupt official to resign; even if I paid nothing for the story, I get the free benefit of a more honest government when the official is held accountable.) In this way, local information is like national defense or fire protection. Markets are unsuited for the efficient production of such public goods because it is too easy for beneficiaries of public goods to "free ride" on the investments of others, and thus individuals who might be tempted to produce such goods know they will not be able to recoup the full economic benefit of their investments.

Second, markets depend on informed consumers, and consumers may overspend on information unrelated to the public interest and underspend for access to information about which they are currently 
ignorant. To the extent consumers attach value to sports and entertainment information, it is probably because such information provides a basis for widespread social conversation, not because it is regarded as intrinsically important. Most people, however, have little idea whether investing in information on particular health risks, technological developments, or public policy debates will have any future payoff in their lives. Lacking any prophetic crystal ball, human beings cannot be expected to vote knowledgeably with their dollars for the development of such information in optimal amounts.

Because of the mismatch between market dynamics and certain aspects of the public interest in information, successful communities have two requirements. One is a public policy regime that, to the extent helpful, shapes incentives in the private market towards the creation, organization, and dissemination of accurate information on topics critical to the public welfare. The second is an array of wellsupported information intermediaries creating, organizing, analyzing, and disseminating information for reasons other than short-term economic gain. The most trusted social institutions for these purposes are undoubtedly universities, public libraries, and public media, such as National Public Radio and the Public Broadcasting Service. These institutions, in deciding what information to create or preserve, do not have to worry about maximizing short-term profits.

What we learn from the activities of today's scientists, social scientists, engineers, humanists, and artists, working in nonprofit settings, may not be clear for months, or years, or ever. In fact, if a nonprofit information environment is truly robust, some avenues of inquiry and development will simply be failures because a vigorous culture of experimentation, by definition, cannot always be successful. The key to success in such an environment is getting well-trained and committed people, motivated to pursue knowledge in the public interest-and, indeed, for its own sake-to pursue ideas wherever they seem to lead. Through such efforts, social understanding, and the menu of ideas, information, and perspectives available for community problem-solving will not be limited to the ideas, information, and perspectives most congenial for presentation by for-profit media.

It must also be said that community needs and available technologies now coincide to prompt a wide array of other nonprofit actors, not traditionally regarded as media entities, to take on roles as publishers of information and brokers of democratic conversation on an unprecedented scale. Government agencies at all levels, along with a seemingly infinite variety of civil society institutions, are now providers, organizers, and analyzers of information on a host of subjects critical to the public interest. Relatively new organizations such as AmericaSpeaks, the Center for Deliberative Polling, and MIT's 
Consensus Building Institute, together with initiatives of longstanding such as the Extension Services of land-grant universities, are now working throughout the country to help communities marshal their information resources in an inclusive way to achieve effective problem-solving and conflict resolution at the local level. These institutions can serve a critical role in enabling individual community members to interact effectively with information, and to help the community create and implement norms of collective engagement with information that produces constructive community dialogue.

Such developments also point plainly to the potential for powerful partnerships between community institutions in support of democratic information flow. Universities and colleges are increasingly active in applied research that joins faculty expertise with the activities of local government and on-the-ground community organizations. Libraries are becoming brokers for civic conversation, and colleges and universities-which frequently own public broadcast licenses-are supporting creative outreach initiatives in community dialogue and problem-solving. Local public broadcasters, both in radio and television, may work with a host of community organizations to support multiple platforms of interactive media through which citizens share information on issues and topics of common concern. So long as each such institution remains true to its fundamental mission and to the values that have earned the public's trust and support, entering into such partnerships can provide an invaluable source of intellectual and communications capital to support a community's democratic life.

\section{CONCLUSION}

It is common in the literature of both politics and journalism to connect information and democracy through the ideal of the informed citizen. A people ignorant of public affairs can hardly be expected to engage in enlightened self-government and from this perspective, one of social science's most robust findings-the apparent ignorance of the American people about huge swaths of their history and civic affairsalways appears disheartening.

The rhetoric of public ignorance, however, can easily obscure three deeper points. First, it is not necessarily critical to the democratic success of any community that every citizen know a great deal about every aspect of civic affairs. As sociologist and journalism historian Michael Schudson has pointed out, the "informed citizen" models just one version of what Americans have historically understood as good citizenship (Schudson 2004). Personal participation in informed 
discourse over public policy is an important way to engage with one's community, but it is not the only way. What is important, however, for meaningful realization of the "informed citizen" model of democracy is that everyone in the community be genuinely afforded the capacity to act as an informed "monitorial citizen" if he or she so chooses, and that the subcommunity of citizens who choose to engage seriously with civic information be fully representative of the entire community.

The second point is that it is too easy to spring from data about public unawareness of civic facts to dismissiveness of public knowledge in general. People are informed in different ways about different things, including their own experience, all of which can contribute to a community's collective or shared identity and collective knowledge. Part of the importance of connectedness is the capacity it creates to share and collectively implement the diverse spheres and levels of knowledge that the public possesses. A community information infrastructure that provides opportunities for bridging knowledge gaps both among individual citizens, and between citizens and institutions, is essential to creating a collectively informed populace and ensuring that collective knowledge is effectively mobilized in implementing democratic accountability and problemsolving.

The final point about information and democracy, however, is perhaps the most profound. Unless a diverse community can use information and discourse as a way of achieving collective outcomes that are deemed generally satisfactory, there is no other way of effectively implementing the values of political freedom and equality. Media critic Jeffrey Scheuer has put the point powerfully: "As a mechanism for seeking or maintaining power, information is the chief alternative to force, and democracy is a way of organizing society around information rather than around force" (Scheuer 2008, 5). That is why, in order to succeed as communities in a democracy, American communities need information and processes to engage with information productively. Without a focus on information, there is simply no path to legitimate government decision-making based on democratic ideals.

Given the democratic information imperative, there exists a menu of community information needs in a democracy that is both compelling and challenging:

- Communities need access to information adequate to support problem-solving, 
coordination,

accountability,

and connectedness.

- Communities need access to the tools and skills that enable all citizens so inclined to participate vigorously in the community's information networks.

- Communities need a robust set of information intermediaries creating information that addresses members of the community in their capacity as fellow citizens.

- Communities need a for-profit media environment attentive to issues of access, diversity, relevance, and power.

- Communities need nonprofit organizations and information practices - public media, libraries, and institutions of higher learning - committed to the creation, organization, and dissemination of factual information and interpretive analysis in a way that takes into account the interests of all community members and in which all community members have opportunities to participate and have a voice.

- Communities need an economic and public policy environment that enables such organizations and practices to thrive.

These needs are unlikely to be met wholly by happenstance. Market forces and the unleashing of private initiative may be essential to their fulfillment, but they will not be sufficient. On the contrary, their fulfillment will depend in part on the purposive actions of citizens, private firms, non-profit entities, and government officials acting with democratic intent-a common determination to promote the creation, organization, analysis, and dissemination of information on an inclusive basis to support meaningful collective selfdetermination. A community so dedicated is a "democratic information community," both by virtue of its aspirations and because of the quality of informed, inclusive self-governance it makes possible. 


\section{REFERENCE LIST}

Bell, Daniel. 1973. The coming of post-industrial society. New York: Basic Books.

Bimber, Bruce. 2003. Information and American democracy:

Technology in the evolution of political power. New York:

Cambridge University Press.

Buchanan, Allen. 2002. Political legitimacy and democracy. Ethics 112: $689-722$.

Dreier, Peter, John Mollenkopf, and Todd Swanstrom. 2004. Place matters: Metropolitics for the twenty-first century. Lawrence, KS: University Press of Kansas.

Environmental Protection Agency. Toxics Release Inventory Program, http://www.epa.gov/tri/(accessed March 11, 2010).

Fireman, Gary D., Ted E. McVay, Jr., and Owen J. Flanigan. 2003. Narrative and consciousness: Literature, psychology and the brain. New York: Oxford University Press.

Florida, Richard. 2008. Who's your city? How the creative economy is making where to live the most important decision of your life. New York: Basic Books.

Fung, Archon, Mary Graham, and David Weil. 2007. Full disclosure: The perils and promise of transparency. Cambridge, MA: Harvard University Press.

Grossman, Lawrence K. 1995. The electronic republic: Reshaping democracy in the information age. New York: Penguin Books.

Hargittai, Eszter. 2002. Second-level digital divide: Differences in people's online skills. First Monday 7, no. 4 (April 1, 2002), http://firstmonday.org/htbin/cgiwrap/bin/ojs/index.php/fm/ article/view/942/864 (accessed March 11, 2010).

Hutchins, Robert. 1947. A free and responsible press - A general report on mass communication: Newspapers, radio, motion 
pictures, magazines, and books. Commission on Freedom of the Press. Chicago: University of Chicago Press.

Knight Commission on the Information Needs of Communities in a Democracy. 2009. Informing communities: Sustaining democracy in the digital age. Washington, D.C.: Aspen Institute.

Lakoff, George. 2008. Letter; 'The political mind.' New York Times, July 6, Arts section.

Nielsenwire blog. MSNBC, CNN top global news sites in March, NY Times top paper, http://blog.nielsen.com/nielsenwire/online_mobile/msnbcand-cnn-top-global-news-sites-in-march/ (accessed March 11, 2010).

Overholser, Geneva. 2006. On behalf of journalism: A manifesto for change. A project of The Annenberg Foundation Trust at Sunnylands in partnership with The Annenberg Public Policy Center of the University of Pennsylvania.

Post, Robert C. 1995. Constitutional domains: Democracy, community, management. Cambridge, MA: Harvard University Press.

Price, Vincent and Peter Neijens. 1997. Opinion quality in public opinion research. International Journal of Public Opinion Research 9: 336-60.

Project for Excellence in Journalism. 2008. The state of the news media 2008: An annual report on American journalism, http://www.stateofthenewsmedia.com/2008/narrative_onlin e_content analysis.php?cat $=1 \&$ media $=5$ (accessed March 11, 2010).

Rachlinski, Jeffrey J. and Cynthia R. Farina. 2002. Cognitive psychology and optimal government design. Cornell Law Review 87: 549-613.

Sawyer, R. Keith. 2005. Social emergence: Societies as complex systems. New York: Cambridge University Press. 
Scheuer, Jeffrey. 2008. The big picture: why democracies need journalistic excellence. New York: Routledge.

Schudson, Michael. 2004. Click here for democracy: A history and critique of an information-based model of citizenship. In Democracy and New Media, edited by Henry Jenkins and David Thorburn, 49-59. Cambridge, MA: The MIT Press.

Thompson, Dennis F. 2008. Deliberative democratic theory and empirical political science. Annual Review of Political Science 11: 497-520.

Wen, Ming, Christopher R. Browning, and Kathleen A. Cagney. 2007. Neighbourhood deprivation, social capital and regular exercise during adulthood: A multilevel study in Chicago. Urban Studies 44: 2651- 71. 